\title{
Factors Influencing Career Development among Nursing Staff at Port- Said Governmental Hospitals
}

\author{
RanaReda Mohammed', Eglal Ahmed Abdel Wahab², Rasha Ibrahim El-Sayed ${ }^{3}$ \\ B.Sc. Nursing, Port Said University ${ }^{1}$; Assistant Prof. of Nursing Administration, Faculty \\ of Nursing, Cairo University²; Lecturer of Nursing Administration, Faculty of Nursing, \\ Port Said University ${ }^{3}$
}

\begin{abstract}
Background:unparalleled changes which the nurses face in the present healthcare system have created an environment in which individual nurses must take control of their careers and futures.Aim:Determine factors influencing career development among nursing staff at Port-Said governmental hospitals. Design: Descriptive correlational design was used. Setting: This study was carried out in all departments at four hospitals affiliated to the ministry of health in Port Said city namely: Port-said general hospital, Port-fouad general hospital, EL-Zhour general hospital and El-Nasr general hospital. Subjects: This study was included two groups, Group I: all nursing managers with total number of (73). Group II:staff nurses,Stratified random sample were done to recruits staff nurses with total number of (274) staff nurses. Tool of date collection: Career Development Questionnaire was used; it includes three factors measured by (95 items): personal factors, Job related factors and organizational factors. Results:Current study revealed that Job related factors have highest score (71.2\%), then personal factors $(68.9 \%)$, followed by organizational factors(66.9\%)which influencing nursing career development. Conclusion: There was statistically significant positive correlation betweenpersonal factors (nurses' personal behaviors, satisfaction, empowerment, career development practice), Job related factors (autonomy, supervisor support)and organizational factors (management support, the career developmental plans) with nursing career development.Recommendations:generalize development of policies and plans for enhancing career development and increase nurses performance. In addition, administration support: through, in-services training programs, provide resource; and opportunities for further education to upgrade the general awareness level of career development strategies
\end{abstract}

Keywords: Career Development, FactorsInfluencing,Nursing Staff 


\section{INTRODUCTION}

The world has changed, technology underpinning the health care system developed significantly. Nursing needs to develop their career to stay up to date with the latest developments, continuing to update their skills and competences to meet health needs effectively and safely (Gyansah \& Guantai, 2018).

Nursing is a profession that is focused on collaborative relationships that promote the most effective outcomes for clients. The practice of nursing is that the assessment, the promotion of health, the availability of care, and the treatment of health to maintain optimal function. Nurses must continually enhance their knowledge and competence through ongoing learning, education and experience (Ontario, 2018).

Career is defined as progress throughout an individual's professional life, which is developed by selecting positions that contribute to professional goals (Patricia, 2016). It is the progress and actions taken by a person throughout a lifetime(Business Dictionary, 2017).Nursing career should be rich, meaningful, autonomousand have access to the prerequisite for growth and creativity (Rahimi, Aazami, \&Mozafari, 2019).

Development is an essential component of a career in nursing to provide evidence-based care, optimizing patient care, enhancing work environments and retaining experienced nurses (Price \& Reichert, 2017). Career development is a continuous and formalized effort by an organization that focuses on enhancing, enriching and empowering the organization's human capital to begin innovative activities to fulfill both the employee's and the organization's goals (Fatima, 2017 ). It represents a progressive engagement with work to reach into well-being, life satisfaction, and identity (Abele, Hagmaier, \&Spurk, 2016).

Several factors that might influence nurses to participate in career development activities. These factors are represented in three factors; personal factors, job-related factors and organizational factors (Ismaiel, Reizian, \&Hamouoda, 2013). The first one is the personal related factors such as personal behaviors, satisfaction, empowerment, and nurses' career development practice. Personal behaviors are important components in nurses' ability to perform a satisfactory job. Career development should begin with an assessment of self as well as one's work environment, job analysis, education, training, job search and acquisition, and work experience to identify his opportunities and needs 
for improvement (Marquis \& Huston, 2015; \&Salah, 2016). . In addition to Heslin, Keatingand Minbashian (2019) who reported that personality has a direct effect on career outcomes.

The second dimension represented in job-related factors encompasses autonomy and supervisory support. Job autonomy and supervisors support will promote work engagement among nurses; They will feel more secure and supported in their decision(Vera, Martínez, Lorente, \& Chambel, 2016).working Environment and conditions are very important and playing an essential role in employees' satisfaction and career development(Kitana \& Karam, 2017). support for nursing career is important to encourage retention and feel more confident(Brook, Aitken, Webb, MacLaren, \& Salmon, 2019).

In addition to the third dimension which stands for the organizational factors containing management support and the career development plans. Career management helps employees select development activities that prepare them to meet their career goals (Noe, Hollenbeck, Gerhart, \& Wright, 2016). Career planning and development connect individual needs and aspirations with organizational needs and opportunities while advising, informing and evaluating its staff on career planning with raising individual development efforts with training and development programs (Chetana\&Mohapatra, 2017). Organizations should encourage employees to seek feedback and could also design training sessions to improve employee career adaptability, promote employee performance, and facilitate career development (Gong, Xu, Van Swol, Zhang, \&Xu, 2020).

\section{Significance of study}

The health care system faces multiple challenges in improving health status of all Egyptians(Kamal Elden, Rizk, \& Wahby, 2016).Nurses play a key role in all healthcare systems in the world. To improve the professional conditions andincrease the quality of care, nurses' career development should be fulfilled in a specific and targeted way(Rahimi, Aazami, \& Mozafari, 2019).Career development is important toattracting, motivating and retaining good quality employees (Sikawa, Waiganjo, \&Otieno, 2016).In addition to enhancing employee's commitment (Hirsh \& Jackson, 2016). It is a way for organizations to improve employee productivity, and performance (Cedaryana,Luddin\&Supriyati, 2018).Thus, it is important to study the factors that are 
influencing nursing career development.So, the present study aims to determine factors influencing career development among nursing staff at Port-Said governmental hospitals.

\section{THE AIM OF STUDY:}

Determine factors influencing career development among nursing staff at Port-Said governmental hospitals.

\section{Research Question:}

1-What are the factors influencing career development among nursing staff at Port-Said governmental hospitals?

\section{SUBJECTS AND METHOD:}

\section{Research design:}

A descriptive research design was used in conducting the study .

\section{Study setting:}

The study was carried out at four governmental hospitals affiliated to Ministry of Health in Port Said governorate, namely Port-said general hospital, Port-fouad general hospital, EL-Zhour hospital and El-Nasr hospital.

\section{Study Subjects:}

The subjects of the study consisted of two groups:

Group I: Included all nursing managers (nursing directors, associates directors, nursing supervisors and head nurses) who were working in the study setting with total number of (73).Where, "27" nursing managers working in Port-Said general hospital, "17" nursing managers working inPort-fouad general hospital, "14" nursing managers working in EL-Zhour hospitaland "15" nursing managers working in El-Nasr hospital.

Group II: Included the staff nurses,Stratified random sample were done to recruits staff nurse. Total sample size is 274 staff nurses which were withdrawn randomly from nurses working in the studied hospitals in proportion to their number of nurses in each hospital. Port Said hospital: "123" nurses, Port Foad hospital: "56" nurses, Al-Zohor Hospital: "54" nurses and Al-Nasr Hospital: "41" nurses. The participants were chosen 
with inclusion criteria, those who actively work duties and they had at least one year of experience in nursing.

\section{Tools for data collection:}

A self-administered questionnaire sheet was utilized for data collection of this study, it divided into two parts:

\section{Part I:personal\& job related data:}

This part aimed to collect data related to the personal\& job related characteristics such as title of the hospital, unit name, age, gender, educational level, marital status, job position, years of nursing experience and experience in current unit.

\section{Part II:Career Development tool:}

This tool was developed by(Ismaiel, Reizian, \& Hamouoda, 2013). The tool was modified to suite sample of study. It consists of (95 items) which grouped in to three factors: the personal factors (50 items) includes personal behaviors (13items), satisfaction (13 items), empowerment (12 items) and nurses' career development practice (12 items). The job factors (27 items) containing autonomy (14 items), supervisory support (13 items). The organizational factors (11 items) encompasses management support (6 items) and the career developmental plans (5 items).

\section{Scoring system:}

Scoring was used to identify the eight factors influencing nurses career development at port-said governmental hospitals. Responses were scored through five point likertscale which included "strongly agree"=5 score, "agree"=4 score, were as a positive responses, which were combined together as "agree" and in contrast Uncertain "=3 score, strongly disagree"=1 score, disagree"=2 score, which were combined together as" disagree "score as well as negative responses. These scores of the items were summedup and were converted into a percent score, means and standard deviations were computed.

\section{Tools Validity:}

The process of validation of the tool was tested for clarity, relevance, applicability, understanding and ease to implement by five experts from nursing administration 
specialty. They were two assistant professor of nursing administration, faculty of nursing, Cairo University and three assistant professor of nursing administration, faculty of nursing, port-said university. The tools were modified based on their comments and suggestionssuch as clarify some statements, and retranslation of certain words. This phase was carried out in a period of six weeks.

\section{Tools Reliability:}

Cronbach's alpha coefficientwas calculated to assess the reliability of the tools through assessing each part/dimension internal consistency. The tool showed good reliability with high Cronbach's alpha coefficient. The reliability of career development tool $\operatorname{was}(0.959)$

\section{Pilot study:}

A pilot study was carried out on $10 \%$ of nursing staff to test the applicability, feasibilityand clarity of data collection tools before starting data collection and to estimate the needed time to fill the data collection sheets. The pilot study was conducted for two weeks; 20-25 minutes was the time needed to complete the questionnaire by each nursing staff.

\section{Field Work:}

The data were collected from nurses by self-administered questionnaire after obtaining an official agreement from the medical and nursing directors of the studied hospitals. Meeting with the directors of nursing service was conducted by the researcher on an individual basis to explain the aim and objectives of the study and to gain their cooperation.The questionnaire sheet was filled in by nurses while they were on duty in the morning shift, afternoon shift and evening shift after the purpose of the study was explained.Data were distributed collected by the researcher at two days per week; data were collected from four hospitals in parallel during the period from July to October 2018.

\section{Ethical Consideration:}

Official permissions through formal agreement were taken from medical and nursing directors of the study settings to carry out the study. An informed consent was obtained from nursing staff to participate in the study after explaining the purpose and nature of 
the study. Nursing staff included in the study were assured about confidentiality of the information gathered and it was used only for the purpose of the study. Nursing staff included in the study were informed about their right to participate in research and their right to refuse or to withdraw from the study at any time.

\section{Statistical Design:}

Data were coded by the researcher and transformed into a specially designed format, so as to be suitable for computer feeding and the data were analyzed using SPSS computer program version 18 (statistical package for social science). Data were presented using descriptive statistics in the form of frequency, percentages for qualitative data, means and standard deviations for quantitative data. Categorical variables were compared using ANOVA test, t-test and Pearson correlation coefficient. The statistical significance was considered at $\mathrm{P}$-value $\leq 0.05$.

\section{RESULTS:}

Table (1): As table show, 347 nurses were participated in this study; the highest percent of nursing staff (43.2\%) are working in Port Said general hospital.the highest percent $(44.1 \%)$ of nursing staff in the age group between $20-<30$ years old. The majority of them $(94.2 \%, 67.7 \%)$ respectively were female and married. As regard to Educational level the highest percentages $(67.7 \%)$ were nursing technical associate diploma, while the minority of them had a nursing baccalaureate degree or higher (3.6\%). Their medians Years of total and in the current position experience were 12.0 and 8.0 respectively.

Concerning the Scores of the factors influence career development, table (2): demonstrates that the highest mean scores were for total of job related factors (71.2 \pm 15.2$)$ which contains job autonomy with mean (77.6 \pm 13.1$)$ and Supervisory support with mean (64.3 \pm 22.6$)$. Followed by Total score of personal factors mean $(68.9 \pm 11.8)$ which contain career developmental practices mean $(80.1 \pm 20.1)$, empowerment mean (74.1 \pm 14.5$)$, Personal behavior mean $(66.2 \pm 12.8)$ and Satisfaction mean (64.4 \pm 18.2$)$. While the total of organizational factors had the lowest mean $(66.9 \pm 19.7)$ which contain career development plans mean was $(69.5 \pm 19.5)$ and Management support mean (64.8 \pm 22.2$)$ as perceived by nursing staff. 
Concerning the relation between the score of the total score of factors influence career development and personal and job related characteristics of nursing staff, table (3): indicate that, there wasstatistically significance relation between nurses working hospitals, marital status and years of nursing experience with total factors influencing nursing career development $(\mathrm{P}<0.0001)$.In addition to, there was statistically significant relationship between Age and Job title with total factors influencing nursing career development $(\mathrm{P}=0.039$ and 0.026 respectively). While, no statistically significant relations could be shown between total factors influencing nursing career development with Gender, Educational level title and Years of experience in current position.

Regarding correlation between the scores of the total score of factors influence career development with some parameters of the personal and job related characteristics among nursing staff, table (4): illustrates that scores of total factors influence career development were statistically significantly correlated positively with nursing staff Age and years of nursing experience $(\mathrm{P}<0.0001)$. In addition to, there was statistically significant relation between total score of factors influence career development and years of experience in current position $(\mathrm{p}=0.040)$.

Table (1): personal and job related characteristicamong the studied nursing staff (n$347)$.

\begin{tabular}{|c|c|c|}
\hline \multirow{2}{*}{ personal and job related characteristics } & \multicolumn{2}{|c|}{ Studied nursing staff } \\
\hline & No. & $\%$ \\
\hline \multicolumn{3}{|l|}{ Hospital } \\
\hline Port Said General Hospital. & 150 & 43.2 \\
\hline Port Foad General Hospital. & 73 & 21.0 \\
\hline Al Zohour Hospital. & 68 & 19.6 \\
\hline Al Nasr Hospital. & 56 & 16.2 \\
\hline \multicolumn{3}{|l|}{ Age (years) } \\
\hline $20-<30$ & 153 & 44.1 \\
\hline $30-<40$ & 114 & 32.9 \\
\hline $40-<50$ & 59 & 17.0 \\
\hline $50-<60$ & 21 & 6.0 \\
\hline Min-Max, Mean \pm SD & $21.0-59.0$ & $32.9 \pm 9.5$ \\
\hline \multicolumn{3}{|l|}{ Gender } \\
\hline Male & 20 & 5.8 \\
\hline Female & 327 & 94.2 \\
\hline Educational level & & \\
\hline
\end{tabular}




\begin{tabular}{|c|c|c|}
\hline $\begin{array}{l}\text { Nursing technical diploma } \\
\text { Nursing technical associate diploma } \\
\text { Nursing bachelor degree or higher }\end{array}$ & $\begin{array}{l}197 \\
103 \\
47\end{array}$ & $\begin{array}{l}56.8 \\
29.7 \\
13.6\end{array}$ \\
\hline $\begin{array}{l}\text { Job title } \\
\text { Nursing director and Supervisor } \\
\text { Nursing Specialist } \\
\text { Nursing Technician }\end{array}$ & $\begin{array}{l}73 \\
19 \\
255\end{array}$ & $\begin{array}{l}21.0 \\
5.5 \\
73.5\end{array}$ \\
\hline $\begin{array}{l}\text { Marital status } \\
\text { Single } \\
\text { Married } \\
\text { Divorced/widow }\end{array}$ & $\begin{array}{l}96 \\
235 \\
16\end{array}$ & $\begin{array}{l}27.7 \\
67.7 \\
4.6 \\
\end{array}$ \\
\hline $\begin{array}{l}\text { Years of nursing experience } \\
\text { Less than } 10 \\
10-<20 \\
20-<30 \\
30-\leq 40\end{array}$ & $\begin{array}{l}126 \\
124 \\
69 \\
28\end{array}$ & $\begin{array}{l}36.3 \\
35.7 \\
19.9 \\
8.1\end{array}$ \\
\hline Min-Max, Median (Q1-Q3) & $1.0-40.0$ & $12.0(5.0-20.0)$ \\
\hline $\begin{array}{l}\text { Years of experience in the current position } \\
\text { Less than } 10 \\
10-<20 \\
20-<30 \\
30-\leq 40\end{array}$ & $\begin{array}{l}196 \\
86 \\
51 \\
14\end{array}$ & $\begin{array}{l}56.5 \\
24.8 \\
14.7 \\
4.0\end{array}$ \\
\hline Min-Max, Median (Q1-Q3) & $1.0-36.0$ & $8.0(2.0-15.0)$ \\
\hline
\end{tabular}

Q1-Q3: Interquartile range

Table (2): Scores of the factors influence career development of the studied nursing $\operatorname{staff}(n=347)$

\begin{tabular}{|l|l|l|}
\hline Tools & Min-Max & Mean \pm SD \\
\hline Factors affect career development & & \\
\hline Job related dimension & & \\
\hline Job Autonomy & $25.0-100.0$ & $77.6 \pm 13.1$ \\
\hline Supervisory support & $16.7-100.0$ & $64.3 \pm 22.6$ \\
\hline Total score of job-related factors & $0.0-100.0$ & $71.2 \pm 15.2$ \\
\hline Personal factors & & \\
\hline Personal behavior & $0.0-100.0$ & $66.2 \pm 12.8$ \\
\hline Empowerment & $22.9-100.0$ & $74.1 \pm 14.5$ \\
\hline Satisfaction & $1.9-100.0$ & $64.4 \pm 18.2$ \\
\hline career development practices & $0.0-100.0$ & $80.1 \pm 20.1$ \\
\hline Total score of personal factors & $25.0-100.0$ & $68.9 \pm 11.8$ \\
\hline Organizational factors & & \\
\hline Management support & $0.0-100.0$ & $64.8 \pm 22.2$ \\
\hline Career development plans & $0.0-100.0$ & $69.5 \pm 19.5$ \\
\hline Total score of organizational factors & $0.0-100.0$ & $66.9 \pm 19.7$ \\
\hline Total Score of factors & $30.4-100.0$ & $69.4 \pm 12.5$ \\
\hline
\end{tabular}


Table (3): Relation between the total score of factors influence career development and the personal and job relatedcharacteristics among the studied staff.

\begin{tabular}{|l|l|l|l|}
\hline & $\mathbf{n}$ & \multicolumn{2}{|l|}{ Total score of factors } \\
\cline { 3 - 4 } personal and job related characteristics & & Mean \pm SD & Sig. \\
\hline Hospital & & & \\
Port Said General Hospital. & 150 & $68.4 \pm 10.8$ & $\mathbf{F}=\mathbf{7 . 2 0 2}$ \\
Port Foad General Hospital. & 73 & $71.7 \pm 12.9$ & $\mathbf{P}<\mathbf{0 . 0 0 0 1 *}$ \\
Al Zohour Hospital. & 68 & $65.2 \pm 13.6$ & \\
Al Nasr Hospital. & 56 & $74.5 \pm 12.5$ & \\
\hline Age (years) & & & \\
20-<30 & 153 & $67.3 \pm 12.5$ & $\mathbf{F}=\mathbf{1 . 4 9 5}$ \\
$30-<40$ & 114 & $69.2 \pm 12.4$ & $\mathbf{P}=\mathbf{0 . 0 3 9} *$ \\
$40-<50$ & 59 & $71.8 \pm 11.5$ & \\
$50-<60$ & 21 & $79.4 \pm 10.7$ & \\
\hline Gender & & & \\
Male & 20 & $70.9 \pm 16.1$ & $\mathrm{t}=0.562$ \\
Female & 327 & $69.3 \pm 12.2$ & $\mathrm{P}=0.575$ \\
\hline Educational level & & $69.9 \pm 11.7$ & $\mathrm{~F}=0.370$ \\
Nursing technical diploma & 197 & $68.9 \pm 14.2$ & $\mathrm{P}=0.691$ \\
Nursing technical associate diploma & 103 & $68.6 \pm 11.8$ & \\
Nursing bachelor degree or higher & 47 & & \\
\hline Job title & & & \\
Supervisor & 73 & $72.6 \pm 11.8$ & $\mathrm{~F}=3.707$ \\
Specialist & 19 & $71.9 \pm 12.9$ & $\mathrm{P}=0.026^{*}$ \\
Technician & 255 & $68.4 \pm 12.5$ & \\
\hline Marital status & & & \\
Single & 96 & $65.2 \pm 12.2$ & $\mathrm{~F}=8.451$ \\
Married & 235 & $71.2 \pm 12.0$ & $\mathrm{P}<0.0001^{*}$ \\
Divorced/widow & 16 & $68.3 \pm 14.6$ & \\
\hline Years of nursing experience & & & \\
Less than 10 & 126 & $67.3 \pm 12.2$ & $\mathrm{~F}=7.090$ \\
10-<20 & 124 & $68.6 \pm 12.6$ & $\mathrm{P}<0.0001^{*}$ \\
20-<30 & 69 & $71.1 \pm 12.2$ & \\
30- $\leq 40$ & 28 & $78.5 \pm 9.6$ & \\
\hline Years of experience in current position & & & \\
Less than 10 & 196 & $68.1 \pm 12.5$ & $\mathrm{~F}=2.422$ \\
10-<20 & 86 & $70.7 \pm 12.1$ & $\mathrm{P}=0.066$ \\
20-<30 & 51 & $71.0 \pm 12.5$ & \\
30- $\leq 40$ & 14 & $75.3 \pm 11.4$ & \\
\hline & & & \\
\hline
\end{tabular}


Table (4): Correlation between the scores of the total score of factors influences career development with some parameters of the personal and job relatedcharacteristicsamong the studied staff.

\begin{tabular}{|l|l|l|}
\hline \multirow{2}{*}{ personal and job relatedcharacteristics } & \multicolumn{2}{|l|}{ Total factors } \\
& \multicolumn{2}{|l|}{ score } \\
\cline { 2 - 3 } & r & P \\
\hline Age (years) & 0.221 & $<0.0001^{*}$ \\
\hline years of nursing experience & 0.209 & $<0.0001^{*}$ \\
\hline years of experience in current position & 0.110 & $0.040^{*}$ \\
\hline
\end{tabular}

r: Pearson correlation coefficient

*significant at $\mathbf{P} \leq \mathbf{0 . 0 5}$

\section{DISCUSSION:}

Nowadays, nurses play a key role in all healthcare systems in the world. To improve the professional conditions and increase the quality of care, nurses' career development should be fulfilled in a specific and targeted way. Development is essential to achieve qualified staff and safe care(Chowdhury \& Chakraborty, 2017).

Several factors that might influence nurses to participate in career development activities. These factors are represented in three factors; the first one is the personal related factor such as personal behaviors, satisfaction, empowerment, and nurses' career development practice. While the second factor represented in job-related factors encompasses autonomy and supervisory support. In addition to the third factor which stands for the organizational factors containing management support and the career development plans that support continuous professional development.

Regarding the personal factor, findingsof the present study revealed that the majority of studied nursing staff working at port-said governmental hospitals have a personal behaviors andpractices for career development as they are self-confident and have the ability to determine their major strengths and weaknesses. Moreover, nurses are satisfied about what they do, have mastered the necessary skills needed for their job, 
anxious to perform well to get opportunities for promotion and more satisfied and confident about their job.This findings might be attributed to most of nursing staff are young age, anxious to perform well to get opportunities for promotion, more satisfied and confident about their job. Moreover, they are looking forward to receive guidance and acceptance from their supervisors.

The study findings were more consistent with Obiunu and Ebunu (2014) who reported that personality and self-esteem play a significant role in career development.Moreover, Sheikhi, Khoshnab, Mohammadi and Oskouie (2016)elaboratedin his study done in Iran teaching hospital that the nurses considered clinical competencies and the mastery of clinical skills are important factors affecting nurses' career advancement and career success. The nurses explained that they were promoted because they regarded their work and duties as important, and tried to do their best.Hedge and Rineer (2017) indicated that employees' ability to manage their careers is influenced by perceptions and behaviors associated with career performance. In addition to Heslin et al (2018) who indicated that, the personality has direct effect on subjective and objective career outcomes.

According to Kim and Beehr (2017) empowerment can influence and direct their own careers. Additionally, Giragama and Sooriyabandara (2018) Study findings revealed that empowerment is significant factors for the career development. Furthermore, Lee and Lee (2018) revealed that job satisfaction and organizational commitment were significant individual factors that affect career development effectiveness. Moreover, Suresh (2018) reported that career development practices has become an important aspect for many employees to retain in the same organization for longer period in order to achieve career development, increase their performance and improve their skills in the work environment.

On the other hand, findings of present study were in disagreement with studies as Rande, Rahawarin, Jamaluddin and Zacharias (2015) who reported that selfassessment, personal development plans, career education and career information do not significantly affect the employee's career development.

Concerning the job factor, it was found that nursing staff have job autonomy appears in performing skills which is essential for the freedom of actions, accept the consequences for their choices which reflects on their self-esteem and self-respect. This 
finding is due to the nursing staff work and takes decisions independently regarding the work and the patient care.

The present study finding was supported by Sia and Appu( 2015) who revealed that autonomy in the workplace plays an important role in generating employees' creative ideas and performance. Work autonomy is generally referred to as employees' freedom, related to their task performance. The participation of employees in decisionmaking and problem solving related to their job may help to improve their work commitment.According to studies conducted byVeraet al (2016) ;\& Malinowska, Tokarz and Wardzichowska (2018)job autonomy and supervisor support promote work engagement among nurses; They feel more secure and supported in their decision.

Moreover, the study findings revealed that there is supervisors support appears in show confidence in their ability to do good job, support for their attempt for improving their performance, informing nurses about opportunities for training or further education. These findings could be attributed to; the supervisors' aware about guide and support nurses to learn from their failures and enhances their performance. The present study finding is consistent with Kim and Beehr (2017) who indicated that empowering leaders contribute to promoting employees' feelings of competence, selfdetermination, meaningfulness, and impact, which in turn positively affect the development of protean career attitudes and career commitment. Furthermore, the study of Hedge and Rineer (2017) reported that supervisor support is important in the development of nurses careers.

On the other hand, the findings of present study were in disagreement with studies as Ismaiel et al (2013) elaborated that the study revealed that there is a lack of supervisors support appears in not informing nurses about opportunities for training or further education, no support for their attempt for improvement and concentrate on failures rather than success.

Mentioning the Organizational Factor, it was apparent that there is management support for nursing staff. In the form of carrying out evaluation processes, ensuring that information is passed on and give feedback about performance. In addition, nursing management provides guidance and career counseling for nursing staff. These finding could be attributed to, that nursing management at port-said hospitals have policy, feedback system, or a recognized evaluation process to support 
nurses for development or continuing education inside hospitals. Therefore, nurses get appropriate attention for their development, interest, innovation or personal goals.

The study findings were similar to some Egyptian studies as Abd Elfatah, Abdel Wahab and El Sayed ( 2018) who showed that the highest percent of studied nursing personnel agreed about "work support" as factors assisted in nursing career development at Benha University Hospital.In addition to Sikawa et al (2016) who elaborated that Training and development, individual counseling, personal career support are important elements for career development.

On the other hand, the study finding was in disagreement with studies asIsmaiel et al (2013)who reported that nurses are lacking the organizational support. In the form of limited information were disseminated about training and education opportunities inside the hospital, the management don't carry any evaluation processes or give feedback about performance. In addition there were no resources, guidance or career counseling is provided.

Regarding to the career development plans the present study found that there is activate education programs, courses, seminars, coaching and monitoring for nursing. Also, nurses are more knowledgeable, oriented and notified about these opportunities. These findings agreed withHedgeand Rineer (2017);\&Chetana et al (2017) their findings reported that Career planning and career management have a positive and significant influence on career development.In addition,Sheikhi et al (2016) revealed that nurses believe that continuing education in the working environment results in promoting knowledge and skill that facilitates career advancement. Also, Rahman, Rahman, Ali and Khan (2016) supported the value of organizational culture, particularly a learning culture, to employees' career development. Career management and planning were also found to be the two main antecedents of career development.

This finding was in accordance with McDonald and Hite (2016) who revealedthat succession planning, mentoring, coaching, training, special assignmentand performance appraisals facilitate career success. In addition, Lee and Lee (2018) who reported that mentoring and coaching was found to be organizational factors that influence job performance improvement through career development. 
On the other hand, the study finding was in disagreement with Khan, Rajasekar and Al-Asfour (2015) who reported that high percentage of employees were not satisfied with the present career development plans and they found lack of transparency and clarity in their career development plans and career paths. Furthermore, Rande et al (2015) who reported that there is lacking of Information and education variable provided or given to employees that have not been able to help the employees to set goals, track and career development.

\section{CONCLUSION:}

Based on the findings of this study it can be concluded that there was statistically significant positive correlation between personal factors (nurses' personal behaviors, satisfaction, empowerment, career development practice), Job related factors (autonomy, supervisor support) and organizational factors (management support, the career developmental plans) with nursing career development.

\section{RECOMMENDATIONS:}

- Development of policies and plans for enhancing career development and increase nurses performance.

- Administration support: through, in-services training programs, provide resource; and opportunities for further education to upgrade the general awareness level of career development strategies.

- Improve the working environment and provide comfort for their work.

- Follow up the performance of nursing staff to know the strengths and weaknesses and develop a plan for improvement and development.

- Development of a rewards system to enhance nurse's motivation for improvement and achievements.

- Introducing of career development plans in the curriculum of the schools of nursing to help students understand how career planning developing the profession.

- Ministry of health should apply the designed training programs to strengthen nursing practice, in order to achieve positive outcomes in health care delivery.

- Managers should prepare theirorganization's career development programs inthe line with the employees' future plans anddesires. 


\section{REFERENCE:}

Abd Elfatah, E. E., Abdel Wahab, E. A., \& El Sayed, H. H. (2018). Assertiveness and Absenteeism and their Relation to Career Development among Nursing Personnel at Benha University Hospital. Egyptian Journal of Health Care, 9(3), 125-137. https://doi.org/10.21608/ejhc.2018.13924

Abele, A.E., T. Hagmaier, \& D. Spurk. 2016. Does career success make you happy? The mediating role of multiple subjective success evaluations. Journal of Happiness Studies 17: 1615-1633. https://doi.org/10.1007/s10902-015-9662-4.

Brook, J., Aitken, L., Webb, R., MacLaren, J., \& Salmon, D. (2019). Characteristics of successful interventions to reduce turnover and increase retention of early career nurses: A systematic review. International Journal of Nursing Studies, 91, 47-59. https://doi.org/10.1016/j.ijnurstu.2018.11.003

Business Dictionary. (2017). Career. Business Dictionary. com. Retrievied October 06, 2017, from Business Dictionary.com.

http://BusinessDictionary.com/definition/career.html.

Cedaryana, Luddin, M. R., \& Supriyati, Y. (2018). Influence of Work Discipline, Career Development and Job Satisfaction on Employee Performance Directorate General Research and Development of Ministry Research, Technology and Higher Education. International Journal of Scientific Research and Management, 6(2), 87-96. https://doi.org/10.18535/ijsrm/v6i2.el02

Chetana, N., \& Mohapatra, A. K. Das. (2017). Career planning and career management as antecedents of career development: A study. Asian Journal of Management, 8(3), 614. https://doi.org/10.5958/2321-5763.2017.00098.1

Chowdhury, S., \& Chakraborty, P. pratim. (2017). Universal health coverage There is more to it than meets the eye. Journal of Family Medicine and Primary Care, 6(2), 169-170. https://doi.org/10.4103/jfmpc.jfmpc

Fatima, F. (2017). Investigating the predecessors and consequences of career development program: empirical evidence from Omani and Emirati employees. Ahead International Journal of Recent Research Review, 1(11), 28-34. 
Giragama, K. W. K. M. W., \& Sooriyabandara, W. M. S. L. H. (2018).Factors affecting the career development of staff in the banking sector: Acase study of a private bank of Srilanka.4th International Conference on Social Sciences, 4, 27-41. https://doi.org/10.17501/icoss.2017.4104

Gong, Z., Xu, Z., Van Swol, L., Zhang, T., \& Xu, J. (2020). Proactive feedback seeking has a positive effect on career adaptability. Social Behavior and Personality: An International Journal, 48(1), 1-12. https://doi.org/10.2224/sbp.8441

Gyansah, S., \& Guantai, K. H. (2018). Career Development in Organizations : Placing the Organization and Employee on the same pedestal to enhance maximum productivity Career Development in Organizations: Placing the Organization and the Employee on the Same Pedestal to Enhance Maximum Produc. European Journal of Business and Management, 10(14), 40-45.

Retrieved from https://www.researchgate.net/publication/327220798

Hedge, J.W. and Rineer, J.R., (2017). Improving Career Development Opportunities Through Rigorous Career Pathways Research. RTI Press Publication No. OP-0037-1703. Research Triangle Park, NC: RTI Press. https://doi.org/10.3768/ rtipress.2017.op.0037.1703

Heslin, P. A., Keating, L. A., \& Minbashian, A. (2019). How Situational Cues and Mindset Dynamics Shape Personality Effects on Career Outcomes. Journal of Management, 45(5), 2101-2131. https://doi.org/10.1177/0149206318755302

Hirsh, W., \& Jackson, C. (2016). Managing Careers in Large Organisations by Wendy Hirsh and Charles Jackson, (June).

Ismaiel, M. H., Reizian, A. E., \& Hamouoda, G. M. (2013). Factors Affective Nurses' Career Development. Journal of American Science, 9(5), 163-172.

Kamal Elden, N. M., Rizk, H. I. I., \& Wahby, G. (2016). Improving Health System in Egypt: Perspectives Improving Health System in Egypt: Perspectives of Physicians. The Egyptian Journal of Community Medicine, 34(1), 45-58. Retrieved from http://ejcm.journals.ekb.eg/article_646_2f00220c734333c1f587644a7ba95525.pdf 
Khan, S. A., Rajasekar, J., \& Al-Asfour, A. (2015). Organizational Career Development Practices: Learning from an Omani Company. International Journal of Business and Management, 10(9), 88-99. https://doi.org/10.5539/ijbm.v10n9p88

Kim, M., \& Beehr, T. A. (2017). Directing our own careers, but getting help from empowering leaders. Career Development International, 22(3), 300-317. https://doi.org/10.1108/CDI-11-2016-0202

Kitana, A., \& Karam, A. A. (2017). The Relationship between Work Environment into Women's Career Development and Job Satisfaction in the United Arab Emirates : a Large Scale Sampling, 6(1), 22-28.

Lee, Y., \& Lee, J. Y. (2018). A multilevel analysis of individual and organizational factors that influence the relationship between career development and job-performance improvement. European Journal of Training and Development, 42(56), 286-304. https://doi.org/10.1108/EJTD-11-2017-0097

Malinowska, D., Tokarz, A., \& Wardzichowska, A. (2018). Job autonomy in relation to work engagement and workaholism: Mediation of autonomous and controlled work motivation. International Journal of Occupational Medicine and Environmental Health, 31(4), 445-458. https://doi.org/10.13075/ijomeh.1896.01197

Marquis, B. L., \& Huston, C. J. (2015). Leadership roles and management functions in nursing: Theory and application. $8^{\text {th }}$ ed. Philadelphia, PA: Lippincoh williams and wiking co. 236-253

McDonald, K., \&Hite, L. (2016). Career Development: A Human Resource Development Perspective, Routledge, New York, NY.

Noe, R.A., Hollenbeck, J.R., Gerhart, B., \& Wright, P.M. (2016). Fundamentals of Human Resource Management (6th ed.). New York: McGraw-Hill Education. 
Obiunu, J. J., \& Ebunu, O. R. (2014). Factors affecting career development of senior secondary school students in Ethiope east local government area, Delta state, Nigeria. International Journal of Guidance and Counseling, 2(1), 005-010.

Ontario, C. of N. of. (2018). Practice Guideline RN and RPN Practice: The Client, the Nurse and the Environment Table of Contents. Environment.

Patricia, S. (2015).Leading and Managing in Nursing (6th ed.), Texas.

Price, S., \& Reichert, C. (2017). The Importance of Continuing Professional Development to Career Satisfaction and Patient Care: Meeting the Needs of Novice to Mid- to Late-Career Nurses throughout Their Career Span. Administrative Sciences, 7(2), 17. https://doi.org/10.3390/admsci7020017

Rahimi, Z., Aazami, S., \& Mozafari, M. (2019). Preparing career development model of Iranian nurses using Delphi technique. Journal of Family Medicine and Primary Care, 8(10), 3160-3165. https://doi.org/10.4103/jfmpc.jfmpc

Rahman, H., Rahman, W., Ali, N., \& Khan, F. (2016). Organizational Learning Culture and Employees' Career Development: Empirical Evidence from Colleges of Malakand Division of Pakistan. Journal of Managerial Sciences, 10(1), 15-29. Retrieved from http://ezproxy.neu.edu/login?url=http://search.ebscohost.com/login.aspx?direct=true\&d $\mathrm{b}=\mathrm{b}$ th \&AN=116345415\&site $=$ bsi-live

Rande, S., Rahawarin, Y., Jamaluddin, A., \& Zacharias, T. (2015). Factors Affecting The Career Development Of Employees In Secretariat Office Of City Samarinda. International Journal of Scientific \& Technology Research, 4(3). Retrieved from www.ijstr.org

Salah, M. R. A. (2016). The impact of training and development on employees performance and productivity. International Journal of Management Sciences and Business $\quad$ Research, 36), 36-70. Retrieved from https://papers.ssrn.com/sol3/papers.cfm?abstract_id=2849769

Sheikhi, M. R., Khoshnab, M. F., Mohammadi, F., \& Oskouie, F. (2016). Skills 
Required for Nursing Career Advancement: A Qualitative Study. Nursing and Midwifery Studies, 5(2), 1-8. https://doi.org/10.17795/nmsjournal30777

Sia, S. K., \& Appu, A. V. (2015). Work Autonomy and Workplace Creativity: Moderating Role of Task Complexity. Global Business Review, 16(5), 772-784. https://doi.org/10.1177/0972150915591435

Sikawa, G. Y., Waiganjo, E., \& Otieno, R. O. (2016). Influence of career development strategy on employee retention in rural public secondary school in Tanzania. An official Publication of Center for International Research Development. British International Journal of Education And Social Sciences, 5(11), 51-67.

Suresh, V. (2018). Impact of HRM Practices on employee retention In Aviation Industry, Qatar. Anglia Ruskin University.

Vera, M., Martínez, I. M., Lorente, L., \& Chambel, M. J. (2016). The Role of Co-worker and Supervisor Support in the Relationship Between Job Autonomy and Work Engagement Among Portuguese Nurses: A Multilevel Study. Social Indicators Research, 126(3), 1143-1156. https://doi.org/10.1007/s11205-015-0931-8

\section{العوامل المؤثرة على التطور المهنى لاى هيئة التمريض فى مستثفيات بورسعيد الحكومية}

$$
\text { رنا رضا محمد1, اجلال أحمد عبد الوهاب2,رشا ابراهيم السيد } 3
$$

بكالوريوس تمريض- جامعة بورسعيد 1, أستاذ مساعد ادارة التمريض- كلية التمريض- جامعة القاهرة2ح, أستاذ

$$
\text { مساعد ادارة التمريض- كلية التمريض- جامعة بورسعيد } 3 .
$$

\section{الخــلاصـة}

التغييرات التي تو اجه الممرضات في نظام الرعاية الصحية الحالي خلقت بيئة يجب أن يتحكم فيها الممرضين فى مسيرتهم المهنية و المستقلية. الهدف: تهدف هذه الدراسة إلى تحديد العوامل المؤثرة على التطور المهنى لاى هيئة التمريض فى مستشفيات بورسعيد الحكومية. أجريت هذه الدراسة في أربعة مستشفيات تابعة لوزارة الصحة في مدينة بورسعيد وهي: مستشفى بورسعيد العام، مستشفى بور فؤاد العام، مستشفى الزهور العام ومستشفى النصر

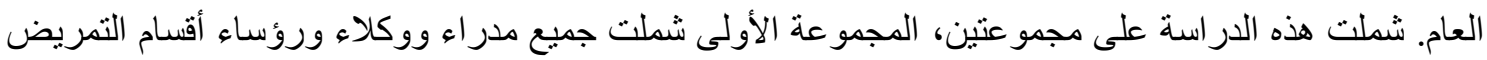
المتو اجدون أثناء تجميع البيانات و الا تقل خبرنهم عن سنة بإجمالي عدد (73). المجموعة الثانبة شملت الممرضين حيث تم إجراء عينة عشو ائية طبقية لتعيين عدد الممرضين فى مستشفيات بورسعيد الحكومية المنو اجدون أثناء 
تجميع البيانات والا تقل خبرتهم عن سنة بإجمالي عدد (274). أداة جمع البيانات: تم استخدام استبيان التطوير المهنى؛ ويشمل ثلاثة عوامل: العوامل الثخصية، العو امل التى تتعلق بالوظيفة والعوامل التى تتعلق بالمستشفى. النتائج: كثفت الدراسة الحالية أن العوامل المرتبطة بالوظيفة أعلى العوامل المؤثرة على التطور المهنى للممرضين (71.2 \%)، يليها العوامل الثخصية (68.9 \%)، ثم العوامل التى تتعلق بالمستشفى (66.9 \%).الخــلاصـة: هناك علاقة إيجابية بين العو امل الثخصية (السلوكيات الثخصية، و التمكين الوظيفى، و الرضـا الوضيفى، وممارسة التطور الوظيفي)، والعوامل التى تتعلق بالوظيفة (الاستقلالالوظيفى، ودعم المشرف) و العوامل التى تتعلق بالمستشفى (دعم الادارة، وخطط التطوير المهنى) مع التطور المهنى للتمريض. التوصيات:

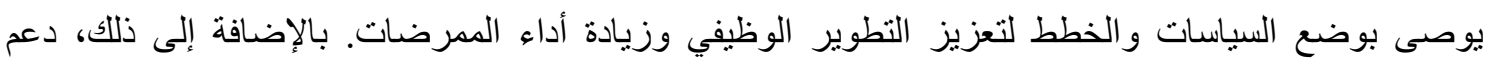
الإدارة: من خلال برامج التدريب، وتوفير الموارد وفرص التعليم لرفع مستوى الوعي باستراتيجيات التطوير 